\title{
PELATIHAN PENGOLAHAN ANEKA KUDAPAN BERBAHAN BAKU PANGAN LOKAL (ALPUKAT) SEBAGAI UPAYA PENINGKATAN EKONOMI KELUARGA DI NAGARI PADANG LAWEH MALALO KECAMATAN BATIPUH SELATAN KABUPATEN TANAH DATAR
}

\section{AVOCADO PROCESSING TRAINING AS A LOCAL RECOURCES TO IMPROVE FAMILY WELFARE AT PADANG LAAWEH MALALO TANAH DATAR REGGENCY WEST SUMATERA}

\author{
Wiwik Gusnita $^{1)^{*}}$, Rahmi Holinesti ${ }^{2)}$, Dikki Zulfikar ${ }^{3)}$, Kasmita ${ }^{4)}$, Ranggi Rahimul Insan ${ }^{5)}$ \\ ${ }^{1)}$ Fakultas Pariwisata dan Perhotelan, Universitas Negeri Padang \\ email: wiwikgusnita@fpp.unp.ac.id \\ ${ }^{2)}$ Fakultas Pariwisata dan Perhotelan, Universitas Negeri Padang \\ email: r.holinesti@gmail.com \\ ${ }^{3)}$ Fakultas Pariwisata dan Perhotelan, Universitas Negeri Padang \\ email: dikkizulfikar@fpp.unp.ac.id \\ ${ }^{4)}$ Fakultas Pariwisata dan Perhotelan, Universitas Negeri Padang \\ email: kasmita70@yahoo.co.id \\ ${ }^{5)}$ Fakultas Pariwisata dan Perhotelan, Universitas Negeri Padang \\ email: ranggirahimulinsan@gmail.com
}

\begin{abstract}
ABSTRAK
Pelatihan pengolahan aneka kudapan berbahan baku pangan lokal (Alpukat) merupakan suatu keagiatan pengabdian kepada masyarakat bertujuan untuk memberikan solusi dari permasalahan yang dihadapi oleh masyarakat khususnya ibu-ibu rumah tangga dalam menghasilkan aneka kudapan yang beranekaragam berbasis bahan pangan lokal. Seorang istri sebagai pengelola rumah tangga, haruslah mampu menggali potensi dan sumber daya yang ada. Jika sumber daya tersebut dapat dikelola dengan baik, maka akan sangat bermanfaat dalam mendongkarak taraf kehidupan dan ekonomi keluarga. Terkait dengan hal tersebut, maka dirasa perlu untuk memberikan keterampilan boga kepada ibu rumah tangga, sehingga diharapkan dapat menambah keterampilan yang dapat digunakan untuk berwirausaha. Berdasarkan analisis masalah di atas, maka usulan model kegiatan adalah: Pelatihan peningkatan kreatifitas membuat aneka kudapan berbasis bahan pangan lokal, serta pendampingan teknis bagi ibu -ibu rumah tangga yang tergabung dalam PKK Padang Laweh Malalo Kabupaten Tanah Datar, mulai dari perencanaan, pelaksanaan, sampai pengelolaan usaha. Metode yang dilakukan dalam kegiatan Pengabdian Kepada Masyarakat yaitu: Memberikan beberapa alat, bahan pelatihan, serta modul materi pelatihan yang akan dilaksanakan; Penyajian materi sesuai dengan isi buku resep ditambah mengenai materi gizi makanan, hygine dan sanitasi, manajemen dapur, dan kewirausahaan terkait jenis produk yang diajarkan serta usaha yang akan dijalankan; serta Pelatihan pembuatan beberapa jenis aneka kudapan berbasis bahan pangan lokal (alpukat). Target luaran kegiatan adalah : Peserta dapat meningkatkan pengetahuan dan keterampilan dalam menghasilkan aneka kudapan; Peserta mampu menata dan mengelola usaha mereka dengan baik dan berkelanjutan; terdapatnya aneka kudapan khas berbasis pangan lokal (Alpukat) yang dapat dijadikan sebagai oleh-oleh bagi konsumen; serta dihasilkannya publikasinya ilmiah hasil kegiatan Pengabdian Kepada Masyarakat ini melalui jurnal nasional maupun media masa.
\end{abstract}

Kata kunci: Ibu Rumah Tangga, Remaja Putri, Pelatihan, Olahan, Alpukat

\section{ABSTRACT}

Training on the processing of various snacks made from local food (Avocado) is a community service activity aimed at providing solutions to problems faced by the community, especially housewives, in producing various snacks based on local food ingredients. A wife as a 
household manager must be able to explore the potential and existing resources. If these resources can be managed properly, it will be very useful in boosting the standard of living and the family economy. Related to this, it is necessary to provide cooking skills to housewives, so that it is hoped that they can add skills that can be used for entrepreneurship. Based on the problem analysis above, the proposed activity model is: Training to increase creativity in making various snacks based on local food, as well as technical assistance for housewives who are members of PKK Padang Laweh Malalo, Tanah Datar Regency, starting from planning, implementing, business management. The methods used in the Community Service activities are: Providing several tools, training materials, and training material modules to be implemented; Presentation of material following the contents of the recipe book plus the material on food nutrition, hygiene and sanitation, kitchen management, and entrepreneurship related to the type of product taught and the business to be run; as well as training in making several types of snacks based on local food ingredients (avocado). The target outputs of the activity are: Participants can improve their knowledge and skills in producing various snacks; Participants can organize and manage their business properly and sustainably; the availability of various typical local food-based snacks (avocado) which can be used as souvenirs for consumers; as well as producing scientific publications of the results of these Community Service activities through national journals and mass media.

Keywords: Housewives, Young Women, Training, Processed, Avocado

\section{PENDAHULUAN}

Undang - undang Sistem Pendidikan Nasional No. 20 Pasal 26 tahun 2006 dan hasil Rakernas PKK II 1984 menjelaskan mengenai perbaikan taraf dan penghidupan keluarga untuk lebih baik oleh sebab itu maka dibutuhkan peningkatan sumber daya manusia (SDM). Salah satu cara yang dibutuhkan yaitu melalui Pendidikan dan pelatihan. Sesuai dengan hal tersebut mengingat peran masyarakat dewasa ini dalam pembangunan sudah tidak lagi dikaitkan hanya dengan bekerja dan jabatan yang dimiliki tetap dalam arti yang lebih luas masyarakat juga berperan secara mandiri dengan segala kemampuan yang dimiliki, yaitu pengetahuan dan keterampilan. Pendidikan, penyuluhan serta pelatihan adalah beberapa cara yang dapat digunakan untuk meningkatkan kualitas masyarakat sehingga dapat membuka kesempatan sebesar-besarnya dalam berpartisipasi dalam menjalankan roda pembangunan.

Sejalan dengan hal di atas maka peran masyarakat dan perkembangan pengetahuan memiliki keselarasan, sehingga generasi muda, anak-anak serta remaja sebagai tunas bangsa perlu lebih ditingkatkan pengembangan diberbagai aspek kehidupan nya, seperti: tingkat gizi dan kesehatan, ketersediaan pangan, pendidikan agama, dan lain-lain serta perlindungan hak-haknya demi kelangsungan hidup, pertumbuhan jasmani, perkembangan rohani, kecerdasan dan kepribadian serta keserasian dalam masyarakat.

Seorang ibu merupakan guru pertama yang mendidik anak-anak tunas bangsa di dalam satuan keluarga, sehingga peran penting seorang ibu dalam tumbuh kembang anak sangat berpengaruh. Selain itu kesetaraan antara seorang wanita dan pria serta hak dan kewajibanya di dalam 
masyarakat mengharuskan seorang wanita

untuk terus menumbuh kembangkan

potensi yang terdapat pada dirinya untuk

menjadi seorang insan yang lebih mandiri

hal ini sejalan apa yang dikemukakan oleh

sulaiman (1994) bahwa seorang wanita

memiliki kebebasan untuk dapat mengembangkan diri di berbagai bidang.

Nagari Padang Laweh Malalo, terletak di Kecamatan Batipuah Selatan Kabupaten Tanah Datar. Luas nagari Padang Laweh Malalo 14,7 km2 atau 17,77 persen dari luas wilayah kecamatan Batipuh Selatan. Nagari Padang Laweh Malalo berjarak 8 km dari ibu kota kecamatan dan 38,4 kilometer dari ibu kota kabupaten. Nagari ini terletak pada koordinat 0,5669 Lintang Selatan dan 100,4883 Bujur Timur. Nagari Padang Laweh Malalo berpenduduk 1.960 jiwa (2017) terdiri dari 946 laki-laki san 1014 perempuan serta 528 rumah tangga.

Berdasarkan data pada Tabel 1 diketahui bahwa nagari Padang Laweh Malalo memiliki produksi tanaman holtikultura yang cukup tinggi dan meningkat setiap tahunnya. Salah satunya adalah Alpukat. Alpukat memiliki potensi yang cukup tinggi untuk diolah menjadi berbagai produk pangan lokal yang memiliki nilai ekonomis tinggi bila di olah menjadi aneka produk kudapan

Tabel 1. Potensi Komoditi Pendukung

\begin{tabular}{lll}
\hline kododitas & $\begin{array}{l}\text { Luas } \\
\text { (ha) }\end{array}$ & $\begin{array}{l}\text { Produksi } \\
\text { (ton) }\end{array}$ \\
\hline Padi sawah & 8,773 & 47,564 \\
\hline Ubi jalar & 5210 & 323,77 \\
\hline
\end{tabular}

\begin{tabular}{lll}
\hline Alpukat & 253,28 & 324 \\
\hline Ikan Air Tawar & 179,03 & 759,4 \\
\hline Pisang & 258,07 & 438,5 \\
\hline Cassiavera & 1602 & 772,94 \\
\hline Kopi & 724,5 & 326
\end{tabular}

Sehubungan pemaparan di atas, Sebagian besar masyarakat Nagari Padang Malalo Kecamatan Batipuh Selatan Kabupaten Tanah Datar memiliki mata pencaharian sebagai petani, dan pedagang dan Sebagian besar ibu-ibu rumah tangga hanya terfokus mengurus rumah tangga sedangkan banyak juga remaja putri pada usia produktif yang hanya menganggur di rumah pasca menyelesaikan Pendidikan mereka di bangku Pendidikan formal. Oleh sebab itu, dirasa perlu diberikan pelatihan boga dengan memanfaatkan potensi lokal yang melimpah yaitu buah alpukat sehingga kemandirian keluarga akan terwujud dengan meningkatnya perekomonian. Selama ini ibuibu rumahtangga di Nagari Malalo sudah bisa dan terbiasa dalam mengolah anekan kudapan untuk sehari-hari, namum jika ditinjau dari segi kualitas kudapan yang dihasilkan masih jauh dari syarat Kesehatan dan juga selera dari konsumen yang selalu mengikuti trend. Selama ini alpukat sebagai komoditas unggulan Nagari Malalo dijual dalam keadaan segar, tentu saja dengan harga jual yang tidak terlalu tinggi. Apabila tidak laku terjual semua pada saat panen melimpah, akan menjadi busuk, sehingga banyak petani yang merasa rugi.

Melalui kegiatan peningkatan 
pengetahuan dan keterampilan diharapkan membuka peluang usaha baru dan meningkatkan nilai jual alpukat selain itu perluasan pemasaran juga akan mendorong usaha yang akan dirintis nantinya berkembang dan dikenal banyak orang.

Berdasarkan observasi yang telah dilakukan, diketahui beberapa permasalahan di masyarakat. Antara lain : kurangnya keterampilan ibu-ibu dan remaja putri dalam mengolah dan menyajikan makanan berbahan baku alpukat, pengetahuan mengenai cara mengolah kudapan dengan bahan baku alpukat masih kurang karena selama ini alpukat hanya di sajikan dalam bentuk jus buah, Penerapan manajemen usaha belum ada, Oleh sebab itu, perlu kiranya ibu-ibu dan remaja putri setempat diberikan pendidikan dan pelatihan keterampilan agar mereka dapat meningkatkan kemampuannya menghasilkan produk berkualitas sekaligus meningkatan perekonomian keluarga.

Berdasarkan analisis masalah yang dikemukakan di atas dapat dapat diidentifikasi masalah yang ada sebagai berikut :

a. Kurangnya pengetahuan seputar tehnologi dalam pengolahan produk makanan oleh ibu-ibu PKK di Nagari Padang Malalo, hal tersebut berpengaruh pada kualitas produk yang mereka olah

b. Kurangnya pengetahuan mereka dalam mengolah makanan berbasis komoditi lokal alpukat. Selama ini mereka hanya mengetahui bahwa alpukat hanya dapat dikonsumsi dalam bentuk jus buah saja, tetapi setelah dilakukan pelatihan diharapkan pengetahuan mereka akan lebih meningkat seputar olehan makanan dari komoditi lokal alpukat dan pada muaranya jiwa kewirausahaan akan berkembang.

c. Kurang mampu dalam manajemen produksi. Pola produksi yang tidak teratur dan terarah akan mengganggu perkembangan usaha ini. Pasokan produk yang tidak teratur akan mengganggu pemasaran. Keterbatasan alat, tenaga kerja dan pasokan bahan baku yang melimpah belum mampu memenuhi permintaan pasar, sehingga memerlukan pengetahuan tentang manajemen produksi untuk memperlancar produksi ide usaha yang akan dikembangkan nantinya.

d. Lemahnya pengelolaan keuangan. Modal menjadi kendala dalam rangka mengembangkan usaha yang lebih besar. Selain itu karena tergolong usaha keluarga maka didalam pengelolaan keuangannya belum melakukan pencatatan yang teratur. Sehingga mitra memerlukan konsultasi dan bimbingan tentang kredit usaha dan pembukuan keuangan yang benar.

e. Kurangnya kualitas Sumber Daya Manusia. Tingkat pendidikan yang relatif rendah sangat mempengaruhi pola pikir dan adopsi teknologi. Oleh karena itu mitra memerlukan transfer teknologi dan pembinaan yang komprehensif dan berkesinambungan

Berdasarkan identifikasi masalah di atas, 
dapat dirumuskan masalah yaitu : kurangnya

pengetahuan dan keterampilan pengolahan

makanan kudapan ber yang berkualitas pada

Ibu-ibu produsen makanan kudapan di dan remaja putri di Nagari Padang Laweh Malalo Kecamatan Batipuh Selatan Kabupaten Tanah Datar.

\section{METODE PELAKSANAAN KEGIATAN}

Dalam meningkatkan kreatifitas dan produktifitas ibu-ibu dan remaja putri di Nagari Malalo, maka sangat dibutuhkan penambahan pengetahuan dan keterampilan kepada mereka yaitu dengan dirancangnya suatu konsep pelatihan. Untuk mencapai tujuan pelatiihan tersebuuutu secara maksimal maka di rancanglah suatu susunan kegiatan yang didalamnya akan menerapkan beberapa metoda pelatihan antara lain:

1. Ceramah. Pada tahap ini diberikan teori dan penjelasan kapada peserta pelatihan mengenai : a. Alpukat sebagai komoditi lokal di Kanagarian Malalo serta lebihankelebihan yang dimiliki oleh alpukat termasuk juga mengenai kandungan gizi nya serta dampak positifnya bagi Kesehatan. b. Teknik pemilihan bahan baku, tehnik pengolahan aneka produk makanan denganbahan baku alpukat sebagai komoditi lokal serta pengemasanya. c. Dasar manajemen untuk meningkatkan potensi waktu, tenaga, dan keuangan peserta, sekaligus perhitungan biaya produksi dan harga jual. $d$. Memberikan motivasi bagi ibu-ibu dan remaja putri untuk berperan aktif meningkatkan ekonomi keluarga.
2. Diskusi dan tanya jawab mengenai materi yang diberikan.

3. Praktek. Pada tahap ini peserta diberikan pelatihan keterampilan mengenai : a. Praktek memilih bahan baku yaitu buah alpukat yang baik untuk diolah menjadi beraneka ragam produk pangan. b. Secara praktek yaitu memilih bahan, mengolah aneka kudapan, berbagai variasi makanan kudapan, penyajian dan mengemas produk. c. Praktek mengolah aneka kudapan berbahan baku komoditi lokal alpukat seperti : nugget alpukat, pancake alpukat, es loli alpukat, es chocky alpukat, dan avocado dessert box. d. Praktek mengemas produk-produk yang dihasilkan, agar memiliki kualitas dan nilai jual yang tinggi.

\section{HASIL DAN PEMBAHASAN}

Pengabdian Kepada Masyarakat merupakan salah satu bagian dari Tridarma Perguruan Tinggi dimana hal tersebut merupakan suatu kewajiban yang harus dilakukan oleh setiap akademisi. Melalui kegiatan Pengabdian masyarakat ini, perguruan tinggi meberikan peranya dalam mengembangkan dan memajukan masyarakat menuju masyarakat yang maju, adil dan sejahtera. Dengan demikian kegiatan pengabdian kepada masyarakat hendaknya diarahkan kepada kegiatan yang memiliki mandaat dan berdampak langsung terhadap kemandirian dan kesejahteraan masyarakat. Upaya ini dapat dilakukan terlebih dahulu dengan suatu pemikiran atau mengkaji ulang hal-hal yang ditemui dalam masyarakat 
dengan memanfaatkan sumberdaya-

sumberaya yang potensial dan belum dimanfaatkan.

Berdasarkan pemikiran di atas maka luaran yang di capai secara umum adalah meningkatnya pengetahuan dan keterampilan mitra yakni tentang pemanfaatan pangan lokal yaitu alpukat. Secara khusus luaran yang dicapai setelah program ini terlaksana adalah:

1. Peningkatan pengetahuan yang lebih baik tentang manfaat alpukat sebagai salah satu pangan lokal yang dapat diolah menjadi beraneka kudapan.

2. Mitra mampu mengolah alpukat menjadi berbagai produk kudapan yang memenuhi persyaratan kesehatan dan keamanan pangan sehingga layak untuk dipasarkan. Dengan demikian hasil olahan yang diproduksi memiliki nilai ekonomi yang lebih tinggi.

3. Mitra mendapatkan sumber pendapatan baru sehingga tidak bergantung pada penghasilan suami. Hal ini dapat meningkatakan ekonomi mitra secara bertahap dan mengurangi pengangguran. Mitra telah dapat memasarkan produk yang dihasilkan pada acara bazar maupun kegiatan lainnya.

4. Mitra dapat menjadi kader dan melanjutkan kegiatan ini pada kelompok masyarakat lainnya.

5. Berdasarkan uji organoleptik yang dilaksanakan, diketahui bahwa produk yang dihasilkan memiliki kualitas yang baik.

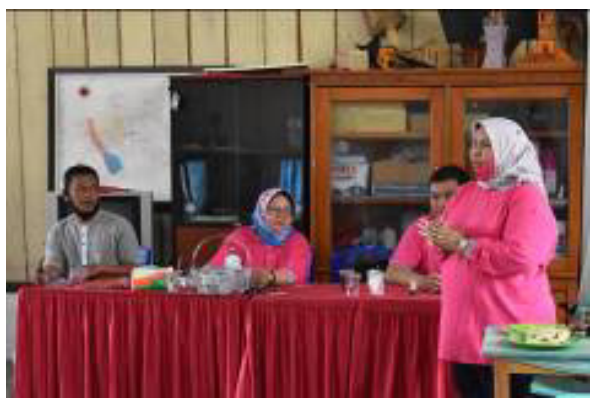

Gambar 1. Pembukaan kegiatan pengabdian bersama Bapak Wali Nagari Padang Malalo

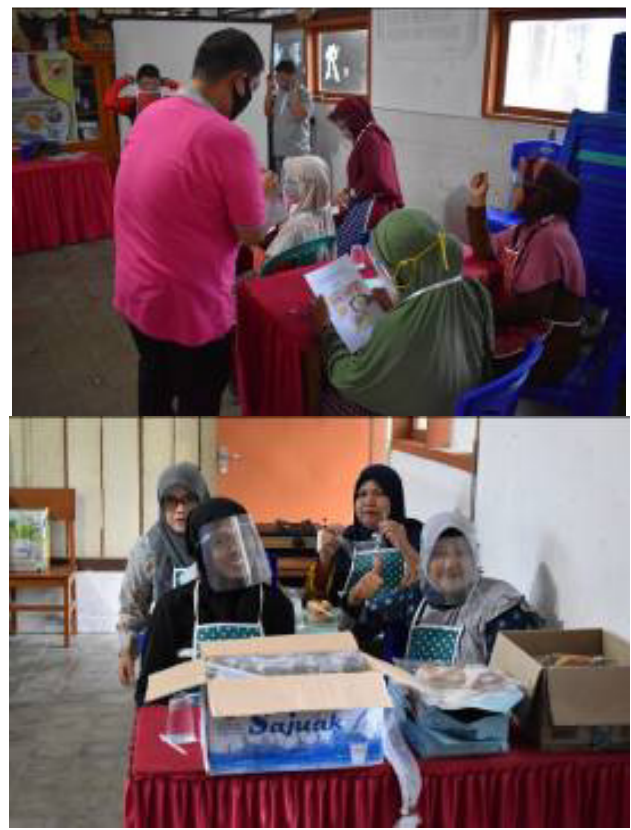

Gambar 2. Pembagian modul untuk penyampaian materi oleh tim pengabdian kepada masyarakat
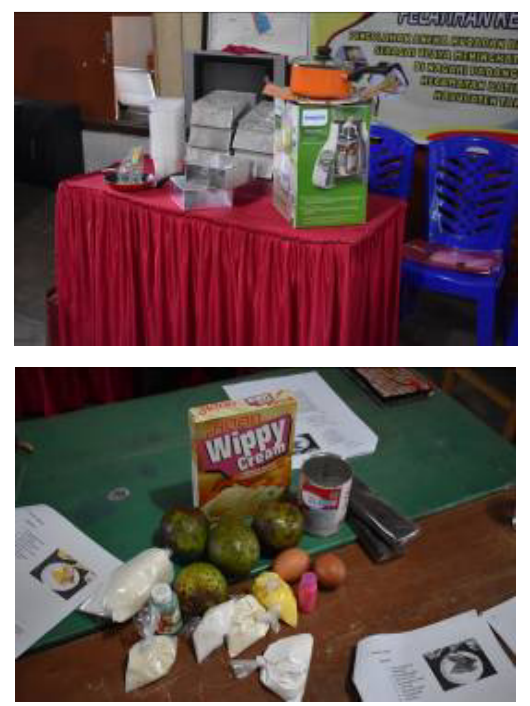

Gambar 3. Alat dan bahan pelatihan olahan alpukat 


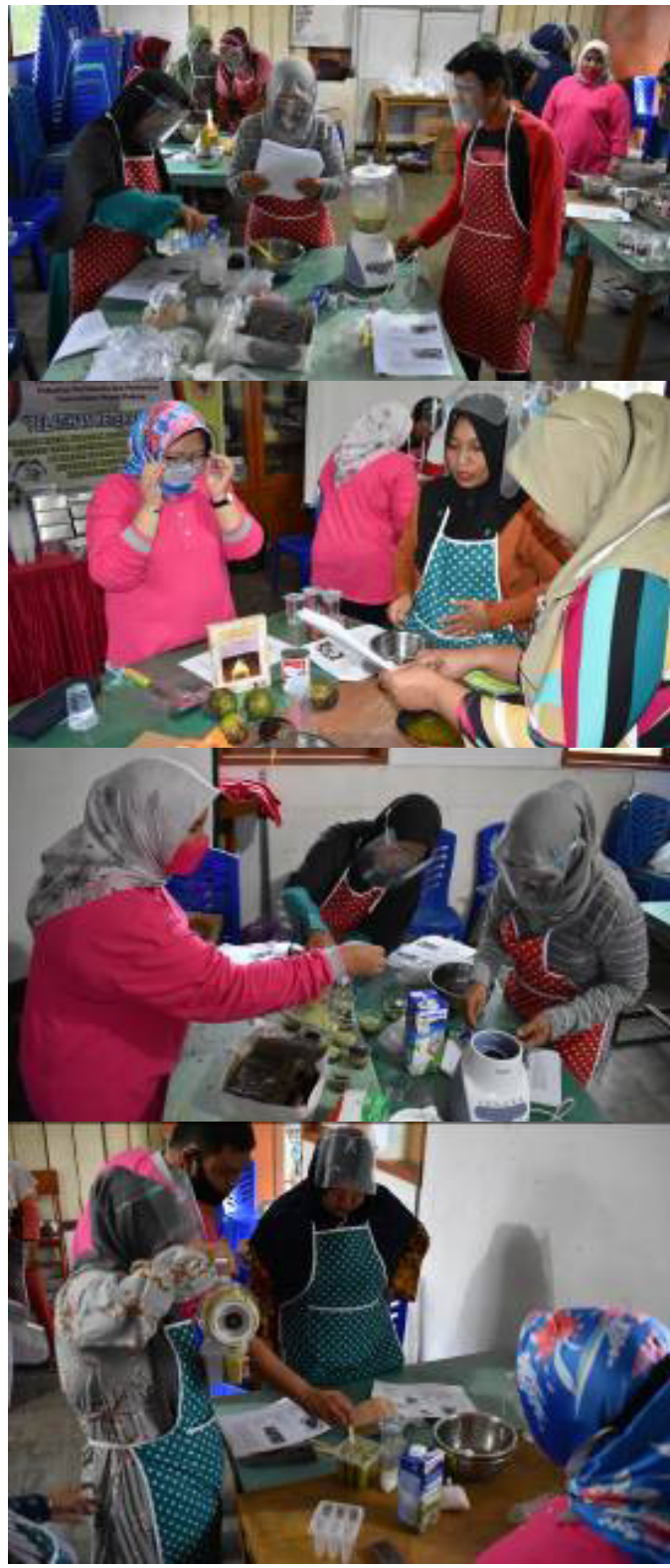

Gambar 4. Peserta pelatihan melaksanakan praktek pembuatan aneka olahan alpukat didampingi oleh instruktur dan tim pengabdian

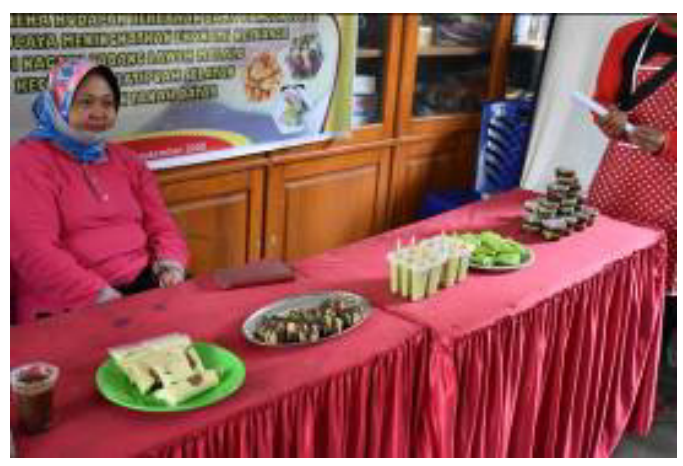

Gambar 4. Hasil praktek pengolahan alpukat menjadi beberapa produk pangan

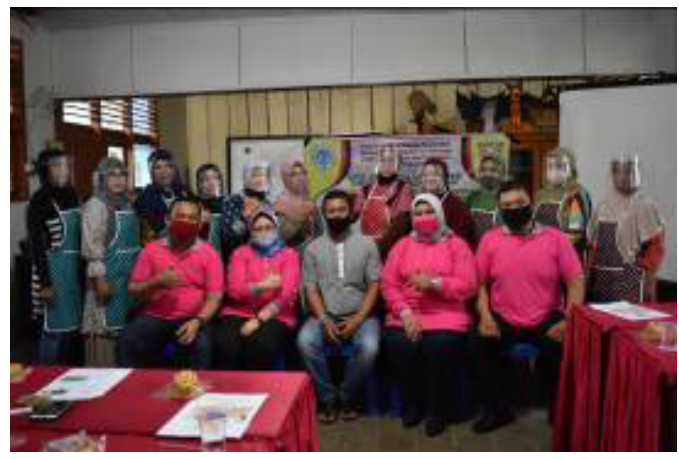

Gambar 5. Evaluasi kegiatan yang telah dilaksanakan serta penutupan pengabdian masyarakat oleh Bapak Wali Padang Laweh Malalo

\section{KESIMPULAN}

Setelah selesainya kegiatan pelatihan pengolahan makanan berbazis bahan lokal alpukat ini harapanya mitra memiliki pengetahuan yang bertambah mengenai pemanfaatan alpukat untuk Kesehatan, memvariasikan produk yang memiliki nilai jual yang lebih tinggi serta mampu mengemas dan memasarkan produk yang dihasilkan. Berdasarkan informasi yang didapatkan mitra sudah mulai menggunakan bahan-bahan pangan lokal lain nya dalam memvariasikan aneka olahan makanan kudapan lainya. Namun, kegiatan bimbingan masih terus dilakukan antara para peserta baik secara langsung maupun tidak langsung. Hal ini dilakukan untuk memantau keberlanjutan pemanfaatan pelatihan di lokasi mitra sesuai dengan tujuan kegiatan pengabdian kepada masyakarat ini.

\section{UCAPAN TERIMA KASIH}

Terima kasih kepada LP2M Universitas Negeri Padang yang telah memberikan dana kegiatan Pengabdian Masyarakat ini melalui program PNBP (BLU) UNP Tahun Anggaran 2020. 


\section{REFERENSI}

[1] Wati, E., Dharmawan, A. H., Damanhuri, D.S., \& Sumarti, T. (2019). 'From Rubber to Oil Palm': Livelihood Structural Transformation of Local and Transmigrant Farmer Households in Minangkabau. Sodality: Jurnal Sosiologi Pedesaan, 7(2), 86-94

[2] BPS. 2018. Tanah Datar dalam Angka Tahun 2018. www.bps.go.id. [17-42020].

[3] Baidar. 2008. Hygiene Dalam Pengolahan Makanan. UNP Press. Padang.

[4] Depkes RI. 2018. Peraturan Kesehatan Jasa Boga. Depkes RI. Jakarta.

[5] Fadiati A. 2013. Pengelolaan Usaha Boga. Departemen Pendidikan dan Kebudayaan. Jakarta.

[6] Frengki, Pangaribuan. 2009. "Aneka Jenis Kue dan Roti Yang Diolah Pada Bagian Pastry Di Hotel Soechi International Medan". Kertas Karya. Medan: Fakultas Sastra-Universitas Sumatera Utara.
[7] Handayani, Titin Hera Widi. 2011. Pengolahan Makanan Indonesia Yogyakarta: Universitas Negeri Yogyakarta.

[8] Heryani, Hesty. 2016. Keutamaan Gula Aren dan Strategi Pengembangan Produk. Banjarmasin: Lambung Mangkurat University Press.

[9] Kasmita. 2012. Cara Produksi Pangan yang Baik. Makalah (Disampaikan Pada Pelatihan Good Manufacturing Practise bagi Pengusaha Pangan Industri Rumah Tangga. Diskoperindag. Padang.

[10] Moehyi S. 2000. Penyelenggaraan Makanan dan Institusi Jasa Boga. Bharata. Jakarta.

[11] D.Zulfikar, W.Gusnita. 2019. "Utilization Of Potato Flour In Making Pukis Cake" Jurnal Pendidikan Dan Keluarga. Vol 112019 